\title{
Announcement of Retraction
}

The editorial board announced this article has been retracted on January 18, 2016.

If you have any further question, please contact us at: jets@ redfame.com

Article Title: Outcomes of an Academic Service-Learning Project on Four Urban Community Colleges Author/s: Debra Abston Greenwood

Journal Title: Journal of Education and Training Studies

ISSN 2324-805X E-ISSN 2324-8068

Volume and Number: Vol. 3, No. 3, 2015

Pages: 61-71

DOI: 10.11114 /jets.v3i3.663 